university by bringing the award of scholarships within the domain of the Joint Matriculation Board, higher papers being set for this special purpose. The good working of the system, he said, was owing to the fact that the Matriculation Board contained a substantial body of representatives of the schools.

In connection with the meetings there was an exhibition of apparatus, etc. Perhaps the most important thing shown was the use of crystal violet to compare the hydrion content of aqueous solutions of acids by the colours obtained on adding measured proportions of the dye. The "weaker" the acid, the nearer is the tint to the violet end of the spectrum. Mr. R. G. Durrant (Marlboroush College) claims that the margin of error in comparison with conductivity data is very narrow, and that his method is both simple and quick. Mr. Durrant also showed the use of malachite-green solution in difierentiating the flames of the alkali and alkaline earth metals by cutting out the orange band from the spectrum; by this means the calcium flame appears bright green and the strontium one ruby-red.

During the ninetcon years of its life the membership of the association has been restricted to the public schools. The basis has now been broadened so as to include science masters in any secondary school which is under the control of a corporate body. The name has therefore been changed to "The Science Masters' $\Lambda$ ssociation." Mr. W. D. Eggar, of Eton College, and Capt. W. J. R. Calvert, of Harrow School, are the new secretaries. Mr. W. W. Vaughan, the Master of Wollington College, was elected president of the association for the coming year.

\section{MR. FISHER AND THE BOARD OF EDUCATION.}

$\mathrm{M}$

R. LLOYD (iEORGE is presumably busy forming his new Government, and rumour has it that many changes of personnel are imminent. Some two years ago, on the formation of the second Coalition Government, a novel departure was made under the stress of war conditions in the selection of men for certain appointments, not in virtue of political services for which due reward must be found, but in respect of peculiar fitness and proved experience of the work to be done. Among those invited to accept office was Mr. H. A. L. Fisher, Vice-Chancellor of the University of Shefficld, who had won the confidence of all classes in the area covered by the operations of the Eniversity by the tact, judgment, and broad sympathy with all forms of education he had displayed in the discharge of his duties. He was invited by $\mathrm{Mr}$. Llovd George to accept the Presidency of the Board of Education vacated by Lord Crewe, and he consented, a seat in the House being found for him in the Hallam division of Shefficld. Mr. Fisher has proved a success, not merely in the discharge of his duties as President, but also in the advocacy of a far-reaching, not to say revolutionary, Education Act, and of a measure of longdelaved justice to the teachers in the shape of a Superannuation Act, which will go far to make the profession of the teacher attractive. $\mathrm{He}$ has won golden opinions by the skill and judgment he displayed in piloting these measures through the Ifouse, and he has breathed a new atmosphere into the Board of Fiducation which "brings hope with it and forwardlooking thoughts." These two mcasures stand to his infinite credit; they still need careful guidance in order to reap their full fruit and to make way for further developments; and yet it is said that a change in Mr. Fisher's position is imminent, born of his very success. No department of the State has suffered more than that of education by the constant changes NO. 2567 , VOL. IO2] of its chief-there have been no fewer than ten since I902-but it would not be so were its status and its vital importance to the national well-being rightly regarded. It ought to rank with the highest Cabinet offices, and be remunerated accordingly. It demands special knowledge and experience for its due discharge, and in $\mathrm{Mr}$. Fisher we have the man who rejoices in both, united with an enthusiasm and devotion but rarely witnesscd. That he should be assigned some other duties in the political sphere would excite a feeling of grave disappointment throughout the country at this critical time.

At the annual meeting of the Incorporatcd Association of Headmasters on January 3 , the president of the association, Mr. F. B. Malim, Master of Haileybury College, proposed, and the Rev. Dr. David, Headmaster of Rugby, seconded, the following resolution, which was adopted unanimously:- "That this association desires to express its profound satisfaction at the educational developments initiated and carried by $\mathrm{Mr}$. Fisher as Minister of Fducation, and its conviction that it is of the first importance in the interests of the nation that Mr. Fisher should continue in that office and should be cnabled to complete the great work of which he has made so admirable a beginning; and that this association would regard it as a national calamity if $\mathrm{Mr}$. Fisher should be required to leave the Board of Education at this juncture."

Following the headmasters' lead, the teachers assembled at the joint conference of educational associations at University College, London, on January 4 , carried unanimously a resolution in the same scnse, which was proposed by Sir Henry Hadow and seconded by Miss Busk. The motion was in the following words :- "This conference, composed of thirtynine educational associations, which is now assembled at University College, London, wishes to urge the importance of retaining $\mathrm{Mr}$. Fisher as Minister of Education. The cducational developments accomplished by him during his period of office have given profound satisfaction to the teaching profession. Further, the confidence established between the Board of Education and teachers through Mr. Fisher's appointment and achievements has inspired teachers with a high sense of their responsibility in the training of the youth of the nation, and it is of the utmost importance that this confidence should bc maintained and strengthened by the continuance of Mr. Fisher in the office of Minister of Education."

OBSERVATTONS ON THE RESULTS OF OIR STSTEM OF EDUCATION.

$\mathrm{MANY}$ problems of education would be solved if a really good scientific test of the results of education could be invented. I can imagine that if such a test were to be applied, say, once a year to all the forty million or so residents in this country, beginning with the British workman and ascending, or descending, to the Houses of Parliament, and even to the Roval Society, the results might be surprising. But as no such test is known, all we can do is to try to form some kind of personal estimate and integration, just as we try to measure lengths and areas by the eye-a method full of fallacies, but unfortunately, perhaps, the only one available. I propose, therefore, to offer for your consideration, as briefly as possible, my own life-notes on the subject.

Let us begin with physicai education. Here, I think, the British system has deservedly set the fashion throushout the world. The young men of most coun-

1 From the presidential address delivered at the annual meeting of the Association of Public School Science Masters on December 3I, 1918, by Col. Sir Ronald Ross K.C.P. K.C.M. (., F.R.S. 